\title{
MANUFACTURING FIRMS' CAPITAL STRUCTURE IN BANGLADESH: COMPARISON BETWEEN LISTED MNCS AND LOCAL COMPANIES
}

\author{
Dr. Syed Mohammad Khaled Rahman \\ Associate Professor \\ Department of Business Administration \\ Shahjalal University of Science \& Technology \\ Sylhet-3114, Bangladesh \\ E-mail: kr15sust@gmail.com \\ Tasmina Chowdhury Tania \\ Assistant Professor \\ Department of Business Administration \\ Shahjalal University of Science \& Technology \\ Sylhet-3114, Bangladesh \\ E-mail: tasmina.tania@gmail.com
}

\begin{abstract}
The capital structure of a firm has immense significance as it has implications on corporate value and financial performance. The basic aim of the research was to analyze and compare the capital structure of Dhaka Stock Exchange (DSE)-listed multi-national companies (MNCs) and local companies of Bangladesh over 24 years (1996-2019). Stratified sampling techniques were applied to the selection of firms. Six financial leverage ratios were used to analyze and compare capital structures. There were significant differences in capital structure between local companies and MNCs as the null hypothesis was rejected. It was also found that the mean equity-financing proportion of domestic companies and MNCs were $65 \%$ and $92.5 \%$ respectively. The proportion of long term debt in total capital employed was very low for both types of companies. MNCs can raise the proportion of both short and long-term debt to take the advantage of financial leverage. Domestic companies can redeem some short term loan and replace some short term debt with long term debt. This research would be useful for corporate financial managers, creditors, and investors to take appropriate financing as well as investment decisions which would affect shareholders' wealth and value of the firm in the long run to a significant extent.
\end{abstract}

Keywords: Capital, Structure, Debt, Leverage, Equity.

JEL Classification Codes: G30, G32, G39

\section{INTRODUCTION}

Capital structure is the composition or proportion of debt and equity capital. It is one of the determinants of the financial performances of corporations. There are two schools of thought in capital structure theories. According to one school of thought, a change of capital structure will change the value of the firm and there is an optimum capital structure at which the value of the 
firm would be maximized and the cost of capital would be minimized. This view is supported by trade-off theory, Modigliani and Miller theory (1963), market signaling theory, etc. According to another school of thought, the capital structure does not matter and it does not influence the value and cost of capital of the firm. The proponents of this view argued that value creation by a firm depends on some other factors such as availing investment opportunities, productivity and efficiency of business operations, using state of the art technologies, corporate governance, ensuring total quality management, compliance with good business practices, etc. rather than on proportion of debt and equity capital. One of the capital structure irrelevance theories is the pecking-order theory which describes the order of financing. Modigliani and Miller's theory (1958) without taxes revealed that firm value is unaffected by the proportion of debt. Despite both capital structure relevance and irrelevance theories, many empirical research works found that capital structure has a significant impact on the value and financial performance of firms. Researchers who found a negative relationship between financial leverage and performance are Fama and Fench(1998), Booth Aivazian, Demirguc-Kunt and Maksimovic (2001), Lima (2011), Islam, Rahman and Khan (2011), Umer Tanveer, Aslam and Sajid (2012), Tsuji (2013), Collins, Filibus, and Clement (2012), etc. Positive association is found by Akbarpour and Aghabeygzadeh (2011), Ahmad, Abdullah, and Roslan (2012), Fosu (2013), Barakat (2014), etc.

MNCs operate in many countries and these firms eventually have many investing and financing opportunities than domestic companies have. In Bangladesh there are very limited numbers of listed MNCs and these are performing better than many local firms. MNCs can lower their cost of debt as they have access to international financial markets and choose the cheapest source of financing. MNCs operating in Bangladesh are the subsidiaries of their respective parent companies and financing decisions are often influenced by the preferences of parents. To minimize country or political risk many MNCs place a significant block of shares to local investors and government of host countries. On the other hand, domestic companies have to raise long-term funds from the local capital market. In this case, the amount, cost, and preference of financing depend on the condition of the capital market and financial institutions of the local country. Besides it, monetary, fiscal, and industrial policies have an impact on choosing the source of financing. Due to differences in Business philosophies as well as host and home countries' government policies, it is expected that the capital structure of local companies may differ from that of MNCs. But a question arises- 'are the differences in leverage ratios significant between two groups and what is the preferred source of financing'? The ultimate goal of every corporation is value creation and proponents of capital structure relevance theory argued that firm value and financial performance largely depends on financial leverage ratios.

\section{PROBLEM STATEMENT}

The capital structure of a firm is important because it affects accounting profitability ratios, cash flows, financial charges, dividend payments, etc. Fixed financial charges such as interest expense are paid against fixed financing cost bearing capital or debt capital. On the other hand, variable financial charges such as dividends are paid against variable financing cost bearing capital or equity capital. Financial charges depend on the amount of capital or the proportionate ratio of debt and equity. So, the proportion of each type of capital and their respective financing cost determine the cost of capital which influences the value of the firm. Besides it, financial leverage has a direct effect on EPS. Dividend per share (DPS) determines the market price of shares of stock and DPS depends on EPS. So, the market value of equity is directly influenced by capital structure. 
Having a greater proportion of equity in capital structure has both advantages and disadvantages. Firms with high equity to asset ratio can avoid financial distress or fixed financial burden. Cash outflow due to interest payment is reduced and the released cash could be used for some other purposes. Besides it, with strong capital base firms can borrow from financial institutions at a low cost of debt because from the perspective of the lender the firm has low financial risk. If a firm's basic earning power is good then a higher proportion of equity capital implies good debt repayment capacity. There are some disadvantages as well. The high proportion of equity would likely result in low firm value as the cost of equity is the most costly among the cost of all other capital components. EPS becomes low due to an increase in the number of outstanding shares. Existing shareholders' control or stake diluted if new shares are issued to raise equity capital. A large number of shareholders with a small stake raise the agency cost of equity. On the other hand, firms can take the advantage of financial leverage if the proportion of debt capital is more. Holding all other factors constant, an increased proportion of debt raise EPS and ROE which in turn enhances the market value of shares. In general, increased use of debt lowers the overall cost of capital and enhances firm value at a low debt level. Tax shield benefit is obtained as interest expense is tax-deductible although Fama and Fench (1998) found that debt does not concede tax benefit. According to the free cash flow theory, the presence of more debt capital ensures financial discipline and the misuse of cash reduces. According to market signaling theory, raise of debt from the capital market conveys a positive signal to the investor, and shares' market price increases. William (2005) found that the use of more debt capital enhances the variability of firms' market value. Besides the capital structure, Iheduru and Chukwuma (2019) in their study found that Nigerian manufacturing firms' profitability ratios were adversely affected by environmental and social costs.

There are some drawbacks of using financial leverage as well. Using a high proportion of debt increases the financial risk and financial distress of firms. The extreme consequence of financial distress is bankruptcy. Too much debt reduces debt repayment capacity which may downgrade the ratings and creditworthiness of firms. Due to high financial risk, firms requiring further borrowed funds can get the fund from financial institutions only at a high-interest rate. Firms may become insolvent because operating income may not be sufficient to cover fixed financial obligations. Jensen (1986) argued that leverage causes a substantial drain of cash due to interest payment and managers take suboptimal leverage for continuous pressure of debt repayment. During difficult times board of directors try to maximize the value of equity at the expense of the value of debt by applying different selfish investment strategies like underinvestment, undertaking riskier projects, and milking the property. Agency cost of debt increases in this situation. Brealey and Myres (1996) identified the legal and administrative costs of a troubled firm as the direct cost of financial distress. They considered impaired ability to run or manage the business as an indirect cost of financial distress. According to Gill and Obradovich (2012), higher financial leverage decreases the firm value by increasing bankruptcy risk. Cuong and Canh (2012) found that a debt ratio exceeding 59.27\% will deteriorate firm value. After examining the capital structure of Bangladeshi commercial banks Siddik, Kabiraj, and Joghee (2017) have identified some reasons for the high cost of debt such as information asymmetry, strong debt covenants, and underdeveloped bond markets.

MNCs have a significant influence on the capital market of Bangladesh. According to Haque (2017), only 13 listed MNCs account for 25\% of market capitalization. In the studies of Hossain (2016) and Amin and Jamil (2015), it was found that the capital structure of Bangladeshi manufacturing companies is dominated by debt as debt ratios are $57 \%$ and $55 \%$ respectively. 
Short term debt dominated long term debt which indicates an aggressive financing strategy. As a result, firms become exposed to roll over and refinancing risk.

\section{LITERATURE REVIEW}

Waliullah and Islam (2018) in their study evaluated the influence of financial leverage ratios on the profitability of MNCs during 2006-2016. MNCs' profitability was measured by ROA and ROE. The study found that Short term debt to total asset ratio has a significant impact on both the profitability ratios while ROE was significantly affected by the long term debt to total asset ratio. By analyzing the capital structure of My Home Industries Ltd., Kusuma (2018) found that the company is burdened with excess debt and debt repayment ability was low. Akani and Ifechi (2017) analyzed the effect of capital structure on the financial performance of listed Nigerian firms during 2008-2016. The authors found that the debt-equity ratio has a significant adverse effect on the accounting profitability ratios of firms. Mawanza and Mugumisi (2013) have analyzed the effect of capital structure on corporate performance of firms of the tourism and hospitality sector in Zimbabwe during 2009-13. The study revealed that capital structure has a significant negative impact on the financial performance of firms. Besides it, capital structure has an adverse effect on share price, market capitalization, and profit after taxes as well as on retained earnings. Hossain and Hossain (2015) in their research on DSE listed manufacturing companies of Bangladesh found some significant determinants of capital structure. They revealed that growth rate, profitability, debt repayment capacity, tax shield, financial charges, free cash flow, agency cost, and payment of dividend harm capital structure. The capital structure theories that are applied in Bangladesh are static trade-off theory and Pecking order theory. Ramadan (2015) in his study analyzed the effect of leverage on Jordanian firms' value over the years 2000-2013. In choosing samples, service-oriented firms were excluded. The study found that leverage ratios have a significant negative impact on profitability.

M'ng, Rahman, and Sannacy (2017) in their research work analyzed firm-specific and macro-economic factors that affect the financing decision of firms situated in Malaysia, Singapore, and Thailand during 2004-2013. The study found that in the case of firms of Malaysia and Singapore firms' profitability has a significant negative effect on the capital structure which implies that more profitable firms prefer equity capital rather than debt capital and vice-versa. Aggarwal (1990) in his research analyzed 474 companies of 20 Asian countries to find out whether capital structure differs across country and industry or not. The study found that capital structure did not significantly vary across firm size but varies across country and industry. In another study, Aggarwal (1981) conducted research on 500 large European firms and found that country-specific and industrial characteristics have a significant influence in designing the capital structure. Esch (2011) has undertaken research work to identify the difference in capital structure between G-7 and E-7 countries. The author found that there were not many differences in gearing ratios between countries of two blocks. The total leverage ratio of G-7 countries was marginally higher but the long-term leverage ratio was marginally lower than that of E-7 countries. The study also found a negative relationship between profitability and leverage ratios. Amin and Jamil (2015) investigated the capital structure of cement companies of Bangladesh and related it with profitability during 2001-2015. In their investigation, it was found that the mean debt ratio was $55 \%$ and short-term debt constitute a significant portion of total debt as the shortterm debt was $42 \%$ of assets. ROA was significantly positively associated with short-term debt ratio. Islam (2016) analyzed the capital structure of 63 DSE listed manufacturing companies of Bangladesh over the years 2008-2012 and found that on average, the total leverage ratio was 
high $(66 \%)$ but the long term leverage ratio was low (14\%) which indicated heavy usage of short term debt. The study found a negative association between leverage and profitability. In choosing among financing alternatives, retained earnings are preferred which is in line with the Pecking order theory. Sadiq, Kachollom, Dasuki, and Yusuf (2017) investigated the impact of capital structure on Nigerian Deposit Money Banks' financial performance during 2006-2015. They recommended the use of long term debt instead of short term debt

Chowdhury and Chowdhury (2010) investigated 77 listed manufacturing companies in Bangladesh to assess the capital structure effect on the market value of firms during 1994-2003. They found that the increased proportion of debt capital enhanced the market value of firms' share'. Alom (2013) analyzed the capital structure of 44 DSE-listed Bangladeshi companies during 2004-2011 and found that means the debt is $62 \%$ of total capital. He also found that financial leverage ratios significantly differ from one industry to another. After analyzing the capital structure of financial institutions of Australia, Akter (2005) found that commercial banks' debt-asset and debt-equity ratios were significantly different from NBFIs. Hossain (2016) analyzed the capital structure of 81 listed manufacturing companies and related it with profitability during 2002-2014. Like the study of Amin and Jamil (2015), they also found a very high proportion of short-term debt $(42.91 \%)$ and a low proportion of long term debt $(12.75 \%)$ in asset financing. ROA was adversely affected by financial leverage. The findings of their study complied with Rouf (2015) who conducted research on the capital structure of listed nonfinancial companies of Bangladesh. Besides ROA, he also revealed that return on sale was also negatively affected by gearing ratios. Siddik et al. (2017) analyzed the effect of capital structure on profitability ratios of Bangladeshi commercial banks during 2005-2014. The study showed that debt ratios have a negative impact on ROA and EPS. Janardhanan and Uma (2020) in their study analyzed the effect of some firm-specific factors on Tobin's Q, ROA, and ROE of 67 financial service firms during 2007-2017. Leverage was one of the firm-specific factors and they found a significant correlation between leverage and profitability ratios at the $10 \%$ level.

Although many research works have been undertaken on the capital structure of Bangladeshi manufacturing companies no research work has been done to compare financial leverage ratios between local firms and MNCs operating in Bangladesh and the purpose of the present study is to cover this research gap. Moreover, no research work has been done on six industrial segments of the manufacturing sector over a period of 24 years and the present study is a comprehensive one.

\section{RESEARCH OBJECTIVES}

The foremost objective of the study is to evaluate and compare the capital structure pattern between local firms and MNCs operating in the manufacturing sector of Bangladesh from 1996 to 2019. Specific objectives are:

- To compare the average debt and equity capital of MNCs and domestic companies and identify firm-wise and year-wise differences.

- To identify and compare six financial leverage ratios of MNCs \& domestic companies.

- To explore the significance of differences in the capital structure of MNCs \& local firms

\section{HYPOTHESIS}

Null hypothesis $\left(\mathrm{H}_{0}\right)$ : Capital structure design of MNCs does not differ significantly from that of domestic companies 


\section{Data and Sample}

\section{MATERIALS AND METHODS}

The population of the study consists of Dhaka Stock Exchange (DSE) listed manufacturing companies operating in Bangladesh. The population is divided into two groups according to types of ownership- domestic companies and multi-national companies (MNCs). Each group was further divided into six strata according to the industrial sector. The strata or industrial sectors have chosen were based on the existence of DSE listed MNCs in the manufacturing sector. A stratified sampling technique was used for selecting firms from different industrial sectors. From each group, seven manufacturing firms were selected from six industrial sectors. The number of sample firms was $14(7 \times 2)$. Secondary data was used in the study. Panel data were collected from annual reports. The study period was from 1996 to 2019.

\section{Data Analysis Technique}

Some descriptive statistical tools like mean, standard deviation, and standard error were used to analyze data. Besides these, inferential statistic such as independent sample t-test has been applied to test the significance of the difference in six leverage ratios between two groups. A normality test has been performed to test the eligibility of the t-test. The normality of data is judged by Kolmogorov-Smirnov and Shapiro-Wilk.

\section{Specification of Variables}

Six financial leverage ratios have been computed as follows:

i. Debt ratio (TD/TA) : Total Debt/ Total Asset

ii. Debt-equity ratio (TD/SE) : Total Debt/Shareholders' Equity

iii.Debt to capital employed ratio (TD/CE): Total Debt/ Capital Employed

iv.Long Term Debt ratio (LTD/TA) : Long Term Debt/ Total Asset

v. Long Term Debt-equity ratio (LTD/SE) : Long Term Debt/Shareholders' Equity

vi.Long Term Debt to capital employed ratio (LTD/CE) : Long Term Debt/ Capital Employed

\section{RESULTS AND DISCUSSIONS}

\section{Comparison of Average Short Term Debt (STD) and Long Term Debt (LTD)}

From table 1, it is observed that STD of domestic companies has increased substantially from 2016. In this year STD was enhanced by more than Tk. 6500 million from the previous year.

Table 1. Short term, long term, and total debt of domestic companies and MNCs (in million Tk.)

\begin{tabular}{|l|l|l|l|l|l|l|}
\hline & \multicolumn{3}{|c}{ Local Firms } & \multicolumn{3}{c|}{ MNCs } \\
\hline Year & STD & LTD & TD & STD & LTD & TD \\
\hline $\mathbf{1 9 9 6}$ & 617.83 & 30.28 & 648.11 & 113.42 & 17.89 & 131.31 \\
\hline $\mathbf{1 9 9 7}$ & 597.75 & 125.57 & 723.33 & 170.25 & 19.60 & 189.85 \\
\hline $\mathbf{1 9 9 8}$ & 733.57 & 140.71 & 874.28 & 163.86 & 69.32 & 233.18 \\
\hline $\mathbf{1 9 9 9}$ & 897.43 & 61.82 & 959.25 & 184.25 & 37.72 & 221.97 \\
\hline $\mathbf{2 0 0 0}$ & 1031.59 & 79.02 & 1110.61 & 73.79 & 50.22 & 124.02 \\
\hline $\mathbf{2 0 0 1}$ & 1386.39 & 187.47 & 1573.86 & 84.58 & 27.89 & 112.46 \\
\hline $\mathbf{2 0 0 2}$ & 1671.31 & 164.29 & 1835.60 & 100.79 & 17.52 & 118.31 \\
\hline $\mathbf{2 0 0 3}$ & 1794.42 & 349.55 & 2143.98 & 316.46 & 104.26 & 420.72 \\
\hline
\end{tabular}




\begin{tabular}{|l|l|l|l|l|l|l|}
\hline $\mathbf{2 0 0 4}$ & 1861.22 & 319.44 & 2180.66 & 318.81 & 75.98 & 394.79 \\
\hline $\mathbf{2 0 0 5}$ & 1458.90 & 303.46 & 1762.36 & 378.46 & 71.21 & 449.67 \\
\hline $\mathbf{2 0 0 6}$ & 1934.89 & 299.39 & 2234.28 & 343.50 & 38.34 & 381.84 \\
\hline $\mathbf{2 0 0 7}$ & 3335.94 & 364.42 & 3700.36 & 375.90 & 33.52 & 409.42 \\
\hline $\mathbf{2 0 0 8}$ & 2362.32 & 331.13 & 2693.44 & 314.18 & 40.38 & 354.56 \\
\hline $\mathbf{2 0 0 9}$ & 1309.80 & 386.63 & 1696.42 & 74.77 & 35.09 & 109.86 \\
\hline $\mathbf{2 0 1 0}$ & 1953.94 & 476.06 & 2430.00 & 33.03 & 24.84 & 57.86 \\
\hline $\mathbf{2 0 1 1}$ & 3823.73 & 458.53 & 4282.27 & 342.79 & 25.74 & 368.53 \\
\hline $\mathbf{2 0 1 2}$ & 5356.95 & 442.22 & 5799.17 & 299.71 & 23.47 & 323.18 \\
\hline $\mathbf{2 0 1 3}$ & 5488.67 & 401.60 & 5890.27 & 311.63 & 21.16 & 332.78 \\
\hline $\mathbf{2 0 1 4}$ & 6163.24 & 425.22 & 6588.46 & 558.13 & 21.46 & 579.59 \\
\hline $\mathbf{2 0 1 5}$ & 4587.86 & 479.28 & 5067.14 & 22.97 & 45.31 & 68.28 \\
\hline $\mathbf{2 0 1 6}$ & 11684.22 & 639.24 & 11709.97 & 438.99 & 20.24 & 459.23 \\
\hline $\mathbf{2 0 1 7}$ & 15277.88 & 742.02 & 15219.19 & 668.50 & 19.78 & 688.28 \\
\hline $\mathbf{2 0 1 8}$ & 18978.08 & 1240.41 & 19209.47 & 1064.77 & 19.33 & 1084.11 \\
\hline $\mathbf{2 0 1 9}$ & 21659.81 & 1261.17 & 22017.62 & 345.01 & 19.33 & 364.34 \\
\hline
\end{tabular}

Source: Annual Reports of Sample Firms (1996-2019) Note: Data compiled by researchers

A sharp increase is seen during 2016-2019. In three years' time, STD increased by more than Tk. 10000 million. In recent years' increased STD was mainly due to increased working capital financing. In initial years, STD was below Tk. 1000 million. Despite some fluctuations in some middle years of the study period, STD showed an increasing trend. MNCs' ainrage STD was far below compared to local firms. In earlier years, STD was below Tk. 200 million and it was hovering around Tk. 300 million from 2003-2008. Only in 2018, STD surpassed Tk. 1000 million. But next year it declined significantly to Tk. 345 million. The Lowest STD is seen in 2015. MNCs' STD showed a fluctuating trend. For both types of companies, LTD was much lower than STD in every year. In the case of local firms, a substantial increase in LTD is seen in the last two years. Before 2009, LTD was below Tk. 400 million. MNCs' LTD surpassed Tk. 100 million only in 2003. But after this year, LTD showed a decreasing trend.

Table 2. MNCs’ Debt \& Equity as \% of Domestic Companies’ Debt \& Equity

\begin{tabular}{|l|l|l|l|c|l|c|c|}
\hline Year & $\begin{array}{l}\text { STD } \\
(\boldsymbol{\%})\end{array}$ & $\begin{array}{l}\text { LTD } \\
(\boldsymbol{\%})\end{array}$ & $\begin{array}{l}\text { TD } \\
(\boldsymbol{\%})\end{array}$ & $\begin{array}{l}\text { Domestic } \\
\text { Co.'s }\end{array}$ & $\begin{array}{l}\text { MNCs } \\
\text { equity }\end{array}$ & $\begin{array}{l}\text { Difference } \\
\text { in equity }\end{array}$ & $\begin{array}{l}\text { MNCs' equity as } \\
\text { \% of Domestic }\end{array}$ \\
\hline 1996 & 18.36 & 59.08 & 20.26 & 686.67 & 562.15 & 124.52 & 81.87 \\
\hline 1997 & 28.48 & 15.61 & 26.25 & 836.15 & 620.43 & 215.72 & 74.20 \\
\hline 1998 & 22.34 & 49.26 & 26.67 & 920.03 & 646.80 & 273.23 & 70.30 \\
\hline 1999 & 20.53 & 61.02 & 23.14 & 1023.05 & 718.39 & 304.66 & 70.22 \\
\hline 2000 & 7.15 & 63.55 & 11.17 & 1134.98 & 800.62 & 334.36 & 70.54 \\
\hline 2001 & 6.10 & 14.88 & 7.15 & 1274.17 & 912.47 & 361.70 & 71.61 \\
\hline 2002 & 6.03 & 10.66 & 6.45 & 1397.64 & 990.33 & 407.31 & 70.86 \\
\hline 2003 & 17.64 & 29.83 & 19.62 & 1510.48 & 1092.86 & 417.62 & 72.35 \\
\hline
\end{tabular}




\begin{tabular}{|l|c|c|c|c|c|c|c|}
\hline 2004 & 17.13 & 23.79 & 18.10 & 1656.03 & 1087.49 & 568.54 & 65.67 \\
\hline 2005 & 25.94 & 23.47 & 25.52 & 2099.85 & 1085.90 & 1013.95 & 51.71 \\
\hline 2006 & 17.75 & 12.81 & 17.09 & 2458.92 & 1219.99 & 1238.93 & 49.61 \\
\hline 2007 & 11.27 & 9.20 & 11.06 & 2677.34 & 1415.14 & 1262.20 & 52.86 \\
\hline 2008 & 13.30 & 12.19 & 13.16 & 3199.85 & 1757.04 & 1442.81 & 54.91 \\
\hline 2009 & 5.71 & 9.08 & 6.48 & 3791.72 & 2089.75 & 1701.97 & 55.11 \\
\hline 2010 & 1.69 & 5.22 & 2.38 & 5275.23 & 2723.46 & 2551.77 & 51.63 \\
\hline 2011 & 8.96 & 5.61 & 8.61 & 6203.32 & 2686.24 & 3517.08 & 43.30 \\
\hline 2012 & 5.59 & 5.31 & 5.57 & 6977.61 & 3110.89 & 3866.72 & 44.58 \\
\hline 2013 & 5.68 & 5.27 & 5.65 & 7931.12 & 3717.68 & 4213.44 & 46.87 \\
\hline 2014 & 9.06 & 5.05 & 8.80 & 8792.92 & 3888.64 & 4904.28 & 44.22 \\
\hline 2015 & 0.50 & 9.45 & 1.35 & 10058.39 & 4337.93 & 5720.46 & 43.12 \\
\hline 2016 & 3.76 & 3.03 & 3.92 & 11355.81 & 5140.70 & 6215.11 & 45.27 \\
\hline 2017 & 4.38 & 2.59 & 4.52 & 12720.25 & 5833.03 & 6887.22 & 45.86 \\
\hline 2018 & 5.61 & 1.56 & 5.64 & 14205.54 & 6753.00 & 7452.55 & 47.54 \\
\hline 2019 & 1.59 & 1.83 & 1.65 & 16915.00 & 7922.12 & 8992.89 & 46.83 \\
\hline Mean & 6.12 & 9.21 & 6.52 & 5212.59 & 2546.38 & 2666.21 & 48.85 \\
\hline
\end{tabular}

Source: Derived from annual reports; Note: Data compiled by researchers

From table 2, it is seen that from 2009, MNCs' STD as \% of domestic firms' STD was very low. In 2015, MNCs' STD was only $0.5 \%$ of domestic firms' STD and in 2019 it was a mere $1.59 \%$. In three years the $\%$ exceeded the $20 \%$ level. On average, MNCs' STD was only $6.12 \%$ of domestic firms' STD. The large variation is seen in the case of LTD. In 2000, MNCs' LTD was $63.55 \%$ while it was only $1.56 \%$ in 2018 . By observing the entire period it is revealed that in earlier years, the proportion was more but in later years it was much less. Mean LTD of MNCs was only $9.21 \%$ of local firms' LTD. As MNCs' both STD and LTD proportion showed a decreasing trend, this was eventually reflected by TD.

Table 2 also shows equity capital of both types of companies as well as MNCs' equity as $\%$ of domestic companies' equity. From the table, it is observed that equity capital has increased gradually over the years and the difference in equity capital also has increased. It indicates that local firms' shareholders' equity grew at a higher rate than MNCs' equity growth. In 1996, domestic companies' equity (Tk. 686.67 million) was near MNCs' equity (Tk. 562.15 million) but in 2019 a large difference in the staggering amount of about Tk. 9000 million was observed. In initial years MNCs' equity was more than $70 \%$ of domestic companies' equity but in recent years it declined to $45-47 \%$. The largest difference in equity capital was seen in 2019 when MNC's equity was $46.83 \%$ of domestic companies' equity.

\section{The proportion of Debt, LTD, and Equity in Asset and Capital Employed}

Table 3 shows the proportion of debt and equity financing in acquiring assets. Domestic companies' average equity financing was $65 \%$ while the mean debt financing proportions was $35 \%$. The lowest proportion of debt financing was in 2010 and the highest proportion was in 
2003 as well as in 2019. From 2013, local firms' proportion of debt was increasing and before this year it fluctuated. By observing the entire period it is seen that in many years equity financing was near two-third of total financing. In the case of MNCs, debt financing was much lower and equity financing dominated to a significant extent. From 1996-2007 the proportion of equity financing was near $90 \%$ and from 2008 onwards it hovered around $96 \%$. The heavy dependence of MNCs on equity financing indicates very low financial risk. On average, debt financing accounts for only $7.5 \%$ while the rest is equity financing. Considering the overall period, more consistency in debt financing is seen in the case of domestic companies. Little fluctuation in proportion debt financing is seen in recent years' capital composition of both types of firms.

Table 3. The proportion of Debt and Equity Financing of MNCs and Domestic companies

\begin{tabular}{|c|c|c|c|c|c|c|c|c|}
\hline \multirow{2}{*}{ Year } & \multicolumn{4}{|c|}{ Domestic Firms } & \multicolumn{3}{c|}{ MNCs } \\
\cline { 2 - 9 } & $\begin{array}{l}\% \\
\text { Debt }\end{array}$ & $\begin{array}{l}\text { \% } \\
\text { equity }\end{array}$ & $\begin{array}{c}\text { LT in } \\
\text { CE }\end{array}$ & $\begin{array}{c}\text { Equity } \\
\text { in CE }\end{array}$ & \% Debt & \% equity & $\begin{array}{c}\text { LTD in } \\
\text { CE }\end{array}$ & $\begin{array}{c}\text { Equity in } \\
\text { CE }\end{array}$ \\
\hline 1996 & 0.43 & 0.57 & 0.22 & 0.78 & 0.12 & 0.88 & 0.05 & 0.95 \\
\hline 1997 & 0.30 & 0.70 & 0.15 & 0.85 & 0.12 & 0.88 & 0.03 & 0.97 \\
\hline 1998 & 0.33 & 0.67 & 0.17 & 0.83 & 0.13 & 0.87 & 0.08 & 0.92 \\
\hline 1999 & 0.34 & 0.66 & 0.14 & 0.86 & 0.09 & 0.91 & 0.04 & 0.96 \\
\hline 2000 & 0.36 & 0.64 & 0.12 & 0.88 & 0.07 & 0.93 & 0.04 & 0.96 \\
\hline 2001 & 0.40 & 0.60 & 0.16 & 0.84 & 0.07 & 0.93 & 0.02 & 0.98 \\
\hline 2002 & 0.42 & 0.58 & 0.15 & 0.85 & 0.05 & 0.95 & 0.01 & 0.99 \\
\hline 2003 & 0.44 & 0.56 & 0.16 & 0.84 & 0.11 & 0.89 & 0.04 & 0.96 \\
\hline 2004 & 0.41 & 0.59 & 0.14 & 0.86 & 0.12 & 0.88 & 0.03 & 0.97 \\
\hline 2005 & 0.38 & 0.62 & 0.12 & 0.88 & 0.15 & 0.85 & 0.05 & 0.95 \\
\hline 2006 & 0.34 & 0.66 & 0.10 & 0.90 & 0.13 & 0.87 & 0.03 & 0.97 \\
\hline 2007 & 0.35 & 0.65 & 0.08 & 0.92 & 0.12 & 0.88 & 0.03 & 0.97 \\
\hline 2008 & 0.32 & 0.68 & 0.06 & 0.94 & 0.10 & 0.90 & 0.03 & 0.97 \\
\hline 2009 & 0.27 & 0.73 & 0.07 & 0.93 & 0.04 & 0.96 & 0.02 & 0.98 \\
\hline 2010 & 0.24 & 0.76 & 0.08 & 0.92 & 0.01 & 0.99 & 0.01 & 0.99 \\
\hline 2011 & 0.28 & 0.72 & 0.08 & 0.92 & 0.04 & 0.96 & 0.01 & 0.99 \\
\hline 2012 & 0.29 & 0.71 & 0.09 & 0.91 & 0.04 & 0.96 & 0.01 & 0.99 \\
\hline 2013 & 0.28 & 0.72 & 0.07 & 0.93 & 0.03 & 0.97 & 0.00 & 1.00 \\
\hline 2014 & 0.29 & 0.71 & 0.07 & 0.93 & 0.04 & 0.96 & 0.00 & 1.00 \\
\hline 2015 & 0.31 & 0.69 & 0.12 & 0.88 & 0.01 & 0.99 & 0.01 & 0.99 \\
\hline 2016 & 0.35 & 0.65 & 0.11 & 0.89 & 0.04 & 0.96 & 0.004 & 0.996 \\
\hline 2017 & 0.39 & 0.61 & 0.10 & 0.90 & 0.05 & 0.95 & 0.004 & 0.996 \\
\hline 2018 & 0.37 & 0.63 & 0.13 & 0.87 & 0.06 & 0.94 & 0.004 & 0.996 \\
\hline 2019 & 0.44 & 0.56 & 0.18 & 0.82 & 0.04 & 0.96 & 0.005 & 0.995 \\
\hline Mea & 0.35 & 0.65 & 0.12 & 0.88 & 0.075 & 0.925 & 0.024 & 0.976 \\
\hline & & & & & & & & \\
\hline
\end{tabular}

Source: Derived from annual reports; Note: Data compiled by researchers

Long term debt and equity constitute the capital employed of a firm. From table 3 , it is also revealed that for local firms, equity capital accounts for near $90 \%$ of total capital employed in most of the years. From 2007-2014 it was above 90\%. It indicates that the firms raised a very low amount of long-term debt compared to equity. MNCs' proportion of long term debt was lower than local firms. It fluctuated from 1-8\% from 1996-2015 but declined to below $1 \%$ level 
from 2016 onwards. Average long term debt financing was only $2.4 \%$ for MNCs while that of domestic companies' was $12 \%$.

\section{Analysis of Financial Leverage Ratios}

Debt to Asset (TD/TA), Debt-Equity (TD/SE) \& Debt-Capital employed (TD/CE) ratio

Table 4 revealed that the debt ratio of domestic companies was much higher than that of MNCs. There were also wide fluctuations as the ranges were from $24.1 \%-44.2 \%$ and from $1.2 \%-$ $14.6 \%$ for domestic companies and MNCs respectively.

Table 4.Yearly average of Leverage ratios based on total debt

\begin{tabular}{|c|c|c|c|c|c|c|}
\hline Year & \multicolumn{2}{|c|}{ Domestic companies } & \multicolumn{3}{c|}{ MNCs } \\
\hline & TD/T & TD/SE & TD/CE & TD/TA & TD/SE & TD/CE \\
\hline 1996 & 0.430 & 2.724 & 2.197 & 0.120 & 0.250 & 0.223 \\
\hline 1997 & 0.303 & 1.776 & 1.586 & 0.121 & 0.229 & 0.219 \\
\hline 1998 & 0.332 & 1.985 & 1.725 & 0.129 & 0.262 & 0.235 \\
\hline 1999 & 0.345 & 1.937 & 1.740 & 0.096 & 0.189 & 0.180 \\
\hline 2000 & 0.367 & 2.049 & 1.820 & 0.067 & 0.114 & 0.103 \\
\hline 2001 & 0.398 & 2.460 & 2.171 & 0.073 & 0.142 & 0.139 \\
\hline 2002 & 0.417 & 2.672 & 2.369 & 0.048 & 0.097 & 0.095 \\
\hline 2003 & 0.440 & 2.826 & 2.496 & 0.108 & 0.258 & 0.216 \\
\hline 2004 & 0.408 & 2.778 & 2.501 & 0.121 & 0.309 & 0.277 \\
\hline 2005 & 0.380 & 1.858 & 1.654 & 0.146 & 0.607 & 0.510 \\
\hline 2006 & 0.344 & 2.108 & 1.956 & 0.133 & 0.551 & 0.486 \\
\hline 2007 & 0.350 & 3.105 & 3.020 & 0.121 & 0.575 & 0.487 \\
\hline 2008 & 0.324 & 1.747 & 1.689 & 0.104 & 0.373 & 0.317 \\
\hline 2009 & 0.272 & 0.938 & 0.863 & 0.040 & 0.081 & 0.077 \\
\hline 2010 & 0.241 & 1.138 & 1.051 & 0.012 & 0.020 & 0.020 \\
\hline 2011 & 0.281 & 1.334 & 1.241 & 0.039 & 0.080 & 0.079 \\
\hline 2012 & 0.288 & 1.484 & 1.379 & 0.044 & 0.083 & 0.083 \\
\hline 2013 & 0.282 & 1.220 & 1.134 & 0.030 & 0.057 & 0.057 \\
\hline 2014 & 0.292 & 1.275 & 1.152 & 0.044 & 0.099 & 0.098 \\
\hline 2015 & 0.308 & 1.157 & 0.959 & 0.014 & 0.030 & 0.028 \\
\hline 2016 & 0.355 & 1.884 & 1.672 & 0.041 & 0.107 & 0.107 \\
\hline 2017 & 0.387 & 2.123 & 1.940 & 0.046 & 0.124 & 0.124 \\
\hline 2018 & 0.369 & 2.136 & 1.887 & 0.057 & 0.165 & 0.165 \\
\hline 2019 & 0.442 & 3.523 & 2.856 & 0.037 & 0.101 & 0.100 \\
\hline Mean & 0.348 & 2.010 & 1.794 & 0.075 & 0.204 & 0.184 \\
\hline
\end{tabular}




\begin{tabular}{|c|c|c|c|c|c|c|}
\hline SD & 0.201 & 2.790 & 2.767 & 0.112 & 0.037 & 0.407 \\
\hline SE & 0.015 & 0.215 & 0.213 & 0.008 & 0.481 & 0.031 \\
\hline
\end{tabular}

Source: Derived from annual reports; Note: Data compiled by the researchers

From 2013 the ratio showed an increasing trend for domestic companies. On average, domestic companies' $34.8 \%$ of assets were financed by debt. In most of the years from 2009, MNC's debt ratio was below 5\%. Compared to the later years, the debt ratio was higher in earlier years. In analyzing the debt-equity ratio it is evident that the total debt of domestic companies was higher than shareholders' equity. In 2019, total debt was more than three times of equity. MNCs' debt-equity ratio was lower than in domestic companies. Year-wise variation was large as it ranged between $2 \%-60.7 \%$. MNCs' debt was $20 \%$ of equity while domestic companies' debt was more than two times of equity. In almost every year, the total debt to capital employed ratio was above 1 for domestic companies which imply that short-term debt was more than equity capital. In 2019, total debt was 2.85 times of capital employed which was a significant increase from the previous year. MNCs' TD/CE ratio was lower than local firms. A significant increase was seen in 2005 but afterward, it started to decline and from 2009 to 2015 it was below $10 \%$. From 2016 it started to increase and rose above 10\%. On average, domestic companies' total is $179.4 \%$ of capital employed while that of MNCs was only $18.4 \%$.

\section{Long-term to Asset (LTD/TA), Long-term debt to Equity (LTD/SE) \& Long term debt to Capital Employed (LTD/CE) ratio}

All leverage ratios of domestic companies based on long term debt were higher than MNCs. From 1999, the LTD/TA ratio of domestic companies was below 10\%. In 2018 the ratio was $6.9 \%$ and in the next year, it increased to $7.4 \%$. MNCs' LTD/TA ratio was very low. Although up to 2007 it was above $2 \%$ in some years from 2009 onwards it declined below 1\%. From 2016 it was even below $0.5 \%$.

Table 5. Yearly average of leverage ratios based on long term debt

\begin{tabular}{|c|c|c|c|c|c|c|}
\hline & \multicolumn{3}{|c|}{ Domestic Companies } & \multicolumn{3}{c|}{ MNCs } \\
\hline Year & LTD/TA & LTD/S & LTD/CE & LTD/TA & LTD/S & LTD/CE \\
\hline 1996 & 0.122 & 0.375 & 0.221 & 0.028 & 0.158 & 0.046 \\
\hline 1997 & 0.104 & 0.239 & 0.154 & 0.023 & 0.103 & 0.033 \\
\hline 1998 & 0.109 & 0.295 & 0.175 & 0.049 & 0.127 & 0.078 \\
\hline 1999 & 0.077 & 0.204 & 0.137 & 0.031 & 0.086 & 0.045 \\
\hline 2000 & 0.061 & 0.180 & 0.125 & 0.031 & 0.067 & 0.041 \\
\hline 2001 & 0.084 & 0.221 & 0.161 & 0.016 & 0.094 & 0.022 \\
\hline 2002 & 0.073 & 0.211 & 0.149 & 0.010 & 0.061 & 0.013 \\
\hline 2003 & 0.086 & 0.236 & 0.161 & 0.025 & 0.112 & 0.043 \\
\hline 2004 & 0.067 & 0.190 & 0.136 & 0.019 & 0.145 & 0.035 \\
\hline 2005 & 0.059 & 0.157 & 0.120 & 0.020 & 0.421 & 0.053 \\
\hline 2006 & 0.052 & 0.126 & 0.099 & 0.012 & 0.420 & 0.033 \\
\hline 2007 & 0.048 & 0.099 & 0.079 & 0.009 & 0.445 & 0.033 \\
\hline 2008 & 0.038 & 0.075 & 0.063 & 0.010 & 0.300 & 0.030 \\
\hline 2009 & 0.041 & 0.091 & 0.071 & 0.009 & 0.065 & 0.016 \\
\hline
\end{tabular}




\begin{tabular}{|c|c|c|c|c|c|c|}
\hline 2010 & 0.049 & 0.105 & 0.077 & 0.003 & 0.009 & 0.005 \\
\hline 2011 & 0.043 & 0.097 & 0.079 & 0.004 & 0.015 & 0.007 \\
\hline 2012 & 0.044 & 0.106 & 0.086 & 0.003 & 0.040 & 0.005 \\
\hline 2013 & 0.038 & 0.086 & 0.073 & 0.002 & 0.013 & 0.004 \\
\hline 2014 & 0.036 & 0.090 & 0.074 & 0.002 & 0.039 & 0.004 \\
\hline 2015 & 0.071 & 0.183 & 0.120 & 0.009 & 0.021 & 0.019 \\
\hline 2016 & 0.055 & 0.141 & 0.111 & 0.000 & 0.004 & 0.004 \\
\hline 2017 & 0.055 & 0.130 & 0.105 & 0.000 & 0.004 & 0.004 \\
\hline 2018 & 0.069 & 0.185 & 0.133 & 0.000 & 0.004 & 0.004 \\
\hline 2019 & 0.074 & 0.257 & 0.182 & 0.000 & 0.005 & 0.005 \\
\hline Mean & 0.065 & 0.170 & 0.120 & 0.013 & 0.115 & 0.024 \\
\hline S.D & 0.077 & 0.222 & 0.133 & 0.012 & 0.392 & 0.057 \\
\hline S.E & 0.005 & 0.017 & 0.010 & 0.002 & 0.030 & 0.004 \\
\hline
\end{tabular}

Source: Derived from annual reports, Note: Data compiled by the researchers

The mean long-term debt was only $6.50 \%$ and $1.30 \%$ of total assets for local firms and MNCs respectively. Compared to equity, long-term debt was low for both types of firms which are evident from the low LTD/SE ratio. For domestic companies, the ratio has increased for the last three years and reached $25.7 \%$ in 2019. During this period, the MNCs' LTD/SE ratio was below 1\%. From 2005 to 2007 this ratio was above $40 \%$ and a significant decrease was seen in $2009(6.5 \%)$. Average long-term debt was $17 \%$ of equity for domestic companies while for MNCs it was $11.5 \%$. Compared to TD/CE ratio, the LTD/CE ratio for both types of companies was substantially low which implies higher usage of STD. The ratio was below $10 \%$ from 20062014 and increased to $18.2 \%$ in 2019 in the case of domestic companies. Except for 2015, MNCs' LTD/CE ratio was below 1\% during the period 2010-2019. This ratio is decreasing for MNCs. Mean LTD/CE ratio was $12 \%$ and $2.4 \%$ for domestic companies and MNCs respectively.

\section{Test of Hypothesis}

Null Hypothesis $\left(\mathrm{H}_{0}\right)$ : Capital structure design of MNCs does not differ significantly from that of domestic companies

Independent samples t-test has been applied to explore whether six financial leverage ratios of MNCs were statistically significantly different from those of domestic firms or not. Two sets of t-statistics for equality of means have been presented in table 6 by assuming both equal and unequal variances of leverage ratios. For choosing the right assumption and its corresponding t-statistic for equality of means, Levene's test for equality of variances has been performed. In Levene's test, the equal variance between the two groups is considered as the null hypothesis. Acceptance or rejection of this null hypothesis depends on the p-value of the Fstatistic. From the table, it is seen that only the F-statistic of LTD/SE is insignificant as p-value > 0.05 and hence the null hypothesis is accepted. So, for LTD/SE assumption of equal variances and in all other cases assumption of unequal variances was applied.

Table 6. Independent Samples t-Test

\begin{tabular}{|c|c|c|c|c|c|c|c|c|}
\hline \multirow[t]{2}{*}{ Equal variances } & \multicolumn{2}{|c|}{$\begin{array}{l}\text { Levene's } \\
\text { Test for } \\
\text { Equality of } \\
\text { Variances }\end{array}$} & \multicolumn{6}{|c|}{ t-test for Equality of Means } \\
\hline & $\mathrm{F}$ & Sig. & $\mathrm{t}$ & $\overline{\mathrm{df}}$ & $\mathrm{Si}$ & Mean & Std. & $95 \%$ C. I. of the \\
\hline
\end{tabular}




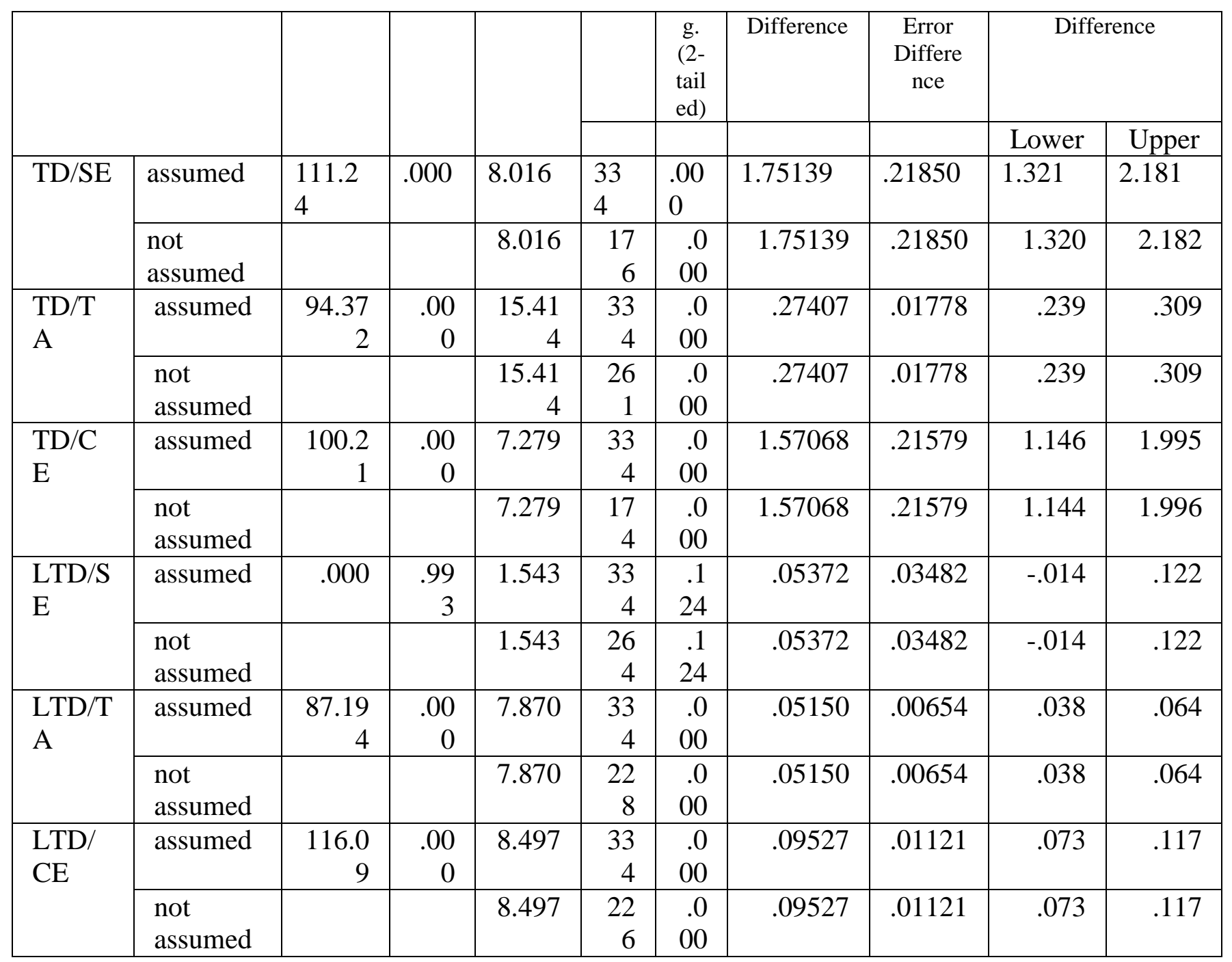

Source: Authors' own calculation, Note: Computation done on SPSS \& Gretl

The normality assumption of all leverage ratios have been fulfilled as $\mathrm{p}$ values of both Kolmogorov-Smirnov and Shapiro-Wilk test were greater than 0.05 for both MNCs and local companies. The normality test is shown in the appendix. So, a t-test was applied using these ratios. In the case of all ratios except LTD/SE, the corresponding two-tailed p-value of t-statistic is 0.000 which is $<0.01$. Rejection of the null hypothesis indicates that there are significant differences in the capital structure of domestic companies and MNCs. Alternatively, it can be said that there are significant differences in debt-equity proportion, debt proportion in asset financing, debt proportion in employed capital, long term debt proportion in asset financing, and long term debt proportion in employed capital between domestic companies and MNCs.

\section{RECOMMENDATIONS}

The total debt of domestic companies is characterized by high short-term debt but very low long term debt. MNCs' proportion of debt is low and total debt is dominated by short-term debt. For the last few years, five sample MNCs did not raise any long term debt. Due to low debt level, both types of companies are not getting full advantage of financial leverage such as debt tax shield, enhancement of EPS, financial discipline, etc. So, some short term debt can be replaced 
by long term debt to get the benefit of long maturity, financial leverage, and reduced refinancing risk. Short-term debt mature very frequently and firms are exposed to refinancing risk and availability risk which can be avoided by raising long-term debt. The borrowing rate can be fixed up upfront and firms can lock-in themselves at that rate up to the maturity of a long-term loan. Because of low gearing ratios, a term loan can be obtained at a comparatively lower interest rate. The average debt-equity ratio of domestic companies was more than 2 which is alarming because equity would not cover the entire debt obligations. Short-term debt should be redeemed to such an amount that debt-equity falls below 1. In most of the years, the TD/CE ratio of domestic companies was above 1 which indicates that short-term debt was more than equity. Excessive short-term debt could enhance the financial distress of domestic companies. MNCs can raise the proportion of both short and long-term debt to take the advantage of financial leverage. As debt is the least costly component of capital, so MNCs can lower their overall cost of capital and hence increases the firm value by raising more debt capital. Strategic level managers of both types of companies should design capital structure in such a way that maximizes firm value and satisfy investors.

\section{CONCLUSION}

Domestic companies' both short term and long term debt proportions were more than MNCs. Financial leverage ratios of domestic companies significantly higher than MNCs as the null hypothesis is rejected in the case of five out of six leverage ratios. So it can be said that the capital structure of MNCs significantly deviates from that of domestic companies. MNCs' average total debt was only $6.52 \%$ of local firms. The financial risk of MNCs was much lower than domestic companies. Both STD and LTD of domestic companies are showing an upward trend. The debt structure of both types of firms is characterized by high STD and low LTD. It can also be said that equity capital is preferred as a proportion of equity was significantly more than the proportion of long term debt. MNCs' heavy dependence on internal financing is revealed. The average total debt was only $20.4 \%$ of MNCs' equity but domestic companies' average total debt was more than two times of equity. For both MNCs and domestic companies proportion of long-term debt was very low compared to short-term debt and equity while domestic companies were burdened with excessive short-term debt. So, strategic level managers of both types of companies should redesign their capital structure to reach an optimum debt level to minimize the cost of financing and maximize firm value. Besides top-level managers of domestic and multinational manufacturing companies, the present study has practical implications on shareholders, creditors, financial institutions, and government as well.

\section{ACKNOWLEDGEMENTS}

The authors are indebted to managers of different levels as well as to the authority of the Dhaka Stock Exchange of Bangladesh for providing secondary data and reports.

\section{REFERENCES}

Aggarwal, R. (1981). International differences in capital structure norms: An empirical study of large European companies. Management International Review, 21(1), 75-88. Retrieved from https://www.jstor.org/stable/40227578

Aggarwal, R. (1990). Capital structure differences among large Asian companies. ASEAN Economic Bulletin, 7(1), 39-53. Retrieved from https://www.jstor.org/stable/25770284 
Ahmad, Z. N., Abdullah, M. H., \& Roslan, S. (2012). Capital structure effect on firms performance: Focusing on consumers and industrials sectors on Malaysian firms.International Review of Business Research Papers, 8(5), 137-55. Retrieved from http://www.sciedu.ca/ijba

Akani, H. W., \& Ifechi, K. N. J. (2017). Effects of capital structure and board structure on corporate performance of selected firms in Nigeria. Indian Journal of Finance and Banking, 1(2), 1-16.

Akbarpour, M., \& Aghabeygzadeh, S. (2011). Reviewing relationship between financial structure and firms performance in firms traded on the Tehran stock exchange. International Journal of Business Administration, 2(4), 175-80. https://doi.org/10.5430/ijba.v2n4p175

Akhtar, S. (2005). The determinants of capital structure for Australian multinational and domestic corporations. The Australian Graduate School of Management, 30, 321-341.

Alom, K. (2013). Capital structure choice of Bangladeshi firms: An empirical investigation. Asian Journal of Finance \& Accounting, 5(1), 320-333.

Amin, \& Jamil (2015). Capital structure and firm performance: Evidence from cement sector of Dhaka stock exchange limited. Journal of Finance and Banking, 13(1\&2).

Barakat, A. (2014). The impact of financial structure, financial leverage and profitability on industrial companies' shares value (applied study on a sample of Saudi industrial companies). Research Journal of Finance and Accounting, 5(1), 55- 66. Retrieved from http://www.iiste.org

Booth, L., Aivazian, V., Demirguc-Kunt, A., \& Maksimovic, V. (2001). Capital structure in developing countries. Journal of Finance, 56, 87-130.

Borman, T. (2019). A Review on capital structure differences in Bangladeshi firms and its impact on their financial performance. $A B C$ Research Alert,7(3). https://doi.org/10.18034/abcra.v7i3.262

Brealey, R. A., \& Myres, S. C. (1996). Principles of Corporate Finance (5 ${ }^{\text {th }}$ ed.). New York: McGraw Hill Companies, pp. 484-486.

Chowdhury, A., \& Chowdhury, S. (2010). Impact of capital structure on firm's value: Evidence from Bangladesh. Business and Economic Horizons, 3(3), 111-122. http://dx.doi.org/10.15208/beh.2010.32

Collins, O. S., Filibus, I. E., \& Clement, A. A. (2012). Corporate capital structure and corporate market value: Empirical evidence from Nigeria. International Journal of Economics and Finance, 4(12), 193-201. http://dx.doi.org/10.5539/ ijef.v4n12p193

Cuong, N.T., \& Canh, N. T. (2012). The effect of capital structure on firm value for Vietnam's seafood processing enterprises. International Research Journal of Finance and Economics, 89, 221-233.

Esch, R. V. (2011). The differences in capital structure between the G-7 countries and the E-7 countries (Master's Thesis). Faculty of Economics and Business, Department of Finance. 
Fama, E. F., \& French, K. R. (1998). Taxes, financing decisions, and firm value. The Journal of Finance, 53 (3), 819-843. Retrieved from http://www.sciedu.ca/ijba

Fosu, S. (2013). Capital structure, product market competition and firm performance: Evidence from South Africa. The Quarterly Review of Economics and Finance, 53, 140-51. Retrieved from http://www.elsevier.com/locate/qref

Gill, A., \& Obradovich, J. D. (2012). The impact of corporate governance and financial leverage on the value of American firms. International Research Journal of Finance and Economics, 91, 46-56. Retrieved from http://www.internationalresearchjournal offinanceandeconomics.com

Haque, S. (2017, December 19). Bringing multinationals to the stock market. The Daily Star. Retrieved from https://www.thedailystar.net /opinion/economics

Hossain, I. (2016). Effects of capital structure and managerial ownership on profitability: Experience from Bangladesh. International Journal of Business and Management, 11(9)

Hossain, M. I., \& Hossain, M. A. (2015). Determinants of capital structure and testing of theories: A study on the listed manufacturing companies in Bangladesh. International Journal of Economics and Finance, 7(4), 176-190. http://dx.doi.org/10.5539/ijef.v7n4p176

Iheduru, N. G., \& Chukwuma, I. R. (2019). Effect of environmental and social cost on performance of manufacturing companies in Nigeria. International Journal of Accounting \& Finance Review, 4(2), 5-12.

Islam, M. E., Rahman, L., \& Khan, A. N. M S. N. (2011). Influence of profitability and risk on capital structure: An analysis on the cement industry of Bangladesh. Journal of Banking \& Financial Services, 5(2), 231-244.

Islam, R. (2016). Determinants of capital structure choices for listed manufacturing companies in Bangladesh. Research Journal of Finance and Accounting 7(7).

Janardhanan, A. K., \& Uma, V. R. (2020). The role of internal control and firm-specific characteristics on firm value: Evidence from Indian financial services sector. Indian Journal of Finance and Banking, 4(1), 117-133.

Jensen, M. C. (1986). Agency costs of free cash flow, corporate finance, and takeovers. American Economic Review, 76, 323-339.

Kusuma, G. D. V. (2018). A study on evaluation of capital structure. Indian Journal of Finance and Banking, 2(2), 42-46.

Lima, M. (2011). An insight into the capital structure determinants of the pharmaceutical companies in Bangladesh.Journal of Finance and Banking, 9(1), 67-84.

M'ng, J. C. P., Rahman, M., \& Sannacy, S. (2017). The determinants of capital structure: Evidence from public listed companies in Malaysia, Singapore and Thailand.Cogent Economics \& Finance, 5, 1-34. https://doi.org/10.1080/23322039.2017.1418609

Mawanza, W., \& Mugumisi, N. (2013). Capital structure and corporate performance: A case for tourism and hospitality sector of Zimbabwe. Global Journal of Commerce and Management Practice, 2(6), 85-90. Retrieved from https://www.longdom.org/articles 
Modigliani, F., \& Miller, M. H. (1963). Corporate income taxes and the cost of capital: A correction. American Economic Review, 36(1), 116-19.

Modigliani, F., \& Miller, M. H. (1958). The cost of capital, corporation finance and the theory of investment. American Economic Review, 48(2), 61-275.

Ramadan, I. Z. (2015). Leverage and the Jordanian firms' value: Empirical evidence. International Journal of Economics and Finance, 7(4), 75-81. http://dx.doi.org/10.5539/ijef.v7n4p75

Rouf, A. (2015). Capital structure and firm performance of listed non-financial companies in Bangladesh.The International Journal of Applied Economics and Finance, 9(1), 25-32.

Sadiq, A. I., Kachollom, P. W., Dasuki, S. I., \&Yusuf, M. (2017). Effect of capital structure on the performance of deposit money banks. International Journal of Accounting \& Finance Review, 1(1), 12-23.

Siddik, M. N. A., Kabiraj, S., \& Joghee, S. (2017). Impacts of capital structure on the performance of banks in a developing economy: Evidence from Bangladesh. International Journal of Financial $\quad$ Studies,5(13), $1-18$. http://dx.doi.org/10.3390/ijfs5020013

Tsuji, C. (2013). Corporate solvency and capital structure: The case of the electric appliances industry firms of the Tokyo stock exchange. International Journal of Economics and Finance, 5(6), 46-54. http://dx.doi.org/10.5539/ijef.v5n6p46

Umar, M., Tanveer, Z., Aslam, S., \& Sajid, M. (2012). Impact of capital structure on firms' financial performance: Evidence from Pakistan. Research Journal of Finance and Accounting, 3(9), 1-12. Retrieved from http://www.iiste.org

Waliullah, G. M., \& Islam, M. (2018). Capital structure and MNC profitability: Empirical evidence from Bangladesh. Proceedings of Academicsera 21st International Conference, Kuala Lumpur, Malaysia, June 1-2.

William, M. (2005). Corporate Finance Theory. USA: Addison-Wesley Education publishers

\section{APPENDICES}

\section{A. Normality tests of six leverage ratios}

\section{Domestic firms:}

Test by Kolmogorov-Smirnova ${ }^{\text {a }}$ :

TD/TA: Statistic0.117; Sig..200*TD/SE: Statistic0.124; Sig..200*

TD/CE: Statistic0.114; Sig..212

LTD/SE: Statistic0.182; Sig..074

\section{Test by Shapiro-Wilk:}

TD/TA: Statistic0.960; Sig..565

TD/CE: Statistic0.962; Sig.. 714
LTD/TA: Statistic0.160; Sig..200*

LTD/CE: Statistic0.191; Sig..066

TD/SE: Statistic0.954; Sig..454

LTD/TA: Statistic0.838; Sig..057 
LTD/SE: Statistic0.819; Sig..069

LTD/CE: Statistic0.973; Sig..089

MNCs:

Test by Kolmogorov-Smirnova ${ }^{a}$ :

TD/TA: Statistic0.198; Sig..058

TD/SE: Statistic0.167; Sig..168

TD/CE: Statistic0.172; Sig..151LTD/TA: Statistic0.159; Sig..232

LTD/SE: Statistic0.235; Sig..085

LTD/CE: Statistic0.167; Sig..255

Test by Shapiro-Wilk:

TD/TA: Statistic0.911; Sig..079

TD/SE: Statistic0.863; Sig..061

TD/CE: Statistic0.804; Sig..063LTD/TA: Statistic0.956; Sig..056

LTD/SE: Statistic0.754; Sig..078

LTD/CE: Statistic0.946; Sig..144

(*This is a lower bound of the true significance. a. Lilliefors Significance Correction; Degree of freedom in all cases is 168)

Source: Authors own computation

\section{B. Acronyms:}

BSC = Bata Shoe Co., BATB = British American Tobacco Bangladesh, GSK = GlaxoSmithKline, $\quad \mathrm{HCL}=$ Heidelberg Cement Ltd., LBD $=$ Linde Bangladesh, $\mathrm{RBB}=$ Reckitt Benckiser Bangladesh Ltd., SBD = Singer Bangladesh, AAL = Aftab Automobiles Ltd., AFL = Apex Footwear Ltd., AMCL = Agricultural Marketing Co. Ltd., BPL = Beximco Pharmaceuticals Ltd., CCL = Confidence Cement Ltd., POC = Padma Oil Company, SPL = Square Pharmaceuticals Ltd.

TD=Total Debt, STD = Short term debt, LTD = Long term debt, TA= Total Asset

$\mathrm{SE}=$ Shareholders' equity, $\mathrm{CE}=$ Capital employed

\section{Copyrights}

Copyright for this article is retained by the author(s), with first publication rights granted to the journal. This is an open-access article distributed under the terms and conditions of the Creative Commons Attribution license (http://creativecommons.org/licenses/by/4.0/) 